\title{
A corpus approach to the history of Russian po delimitatives
}

Hanne Martine Eckhoff, University of Oxford

hanne.eckhoff@mod-langs.ox.ac.uk

\begin{abstract}
This paper gives an example of how enriched diachronic treebank data can shed new light on an old and conflicted topic, even when that topic is primarily morphological and semantic in nature rather than syntactic. The topic is the rise of the Russian po delimitatives, a change seen as crucial in most accounts of the history of Russian aspect, since it represents a major step in generalising the derivational aspect system. Earlier accounts concur that the po delimitatives spread fairly recently, too recently for the development to be connected to the loss of the aorist tense, which also had delimitative readings with atelic verbs. Using treebank data from the Tromsø Old Russian and OCS Treebank, enriched with tags for derivational morphology and semantics, I show that the po delimitatives were not marginal even in the earliest Slavic sources, neither in terms of frequency nor semantics, and that they first complemented and then competed with the delimitative aorists. It can thus be claimed that the exotic po delimitatives grew organically out of the old Indo-European inflectional aspect system.
\end{abstract}

Dans cet article, je montre comment les données d'un corpus arboré enrichi peuvent éclairer un vieux thème controversé, même si ce thème est d'une nature morphologique et sémantique plutôt que syntaxique. Le thème en question est l'essor du délimiteur po en russe, un changement jugé essentiel par la majorité des œuvres traitant de l'histoire de l'aspect en russe. La raison en est que cet essor représente un pas important vers la généralisation du système de l'aspect dérivationnel. Les analyses précédentes sont d'accord que la diffusion du délimiteur po a eu lieu assez récemment, trop récemment pour que l'évolution puisse être mise en relation avec la perte de l'aorist, qui, lui aussi, se prêtait à une interprétation délimitative avec des verbes atéliques. En utilisant des données du corpus arboré de Tromsø Old Russian and OCS Treebank, doté d'une annotation indiquant la morphologie dérivationnelle ainsi que la sémantique, je montre que les délimiteurs po n'ont jamais été marginaux, même pas dans les sources les plus anciennes du slave, ni en ce qui concerne leur fréquence, ni en ce qui concerne leur sémantique. Dans un premier temps, ils complémentaient l'aorist délimitatif, alors que par la suite, il entra en concurrence avec celui-là. Conséquemment, on peut maintenir que les délimiteurs po sont des descendants directs du système flexionnel de l'aspect de l'ancienne langue indo-européenne.

Der vorligende Aufsatz zeigt ein Beispiel dafür, wie angereicherte diachrone Baumbankdaten ein altes und widersprüchliches Thema neu beleuchten können, auch wenn dieses Thema eher morphologisch und semantisch als syntaktisch ist. Das Thema ist der Anstieg der russischen po-Delimitativen; ein Wandel, der in den meisten Berichten über die Geschichte des russischen Aspekts als entscheidend angesehen wird, da er einen wesentlichen Schritt bei der Verallgemeinerung des ableitenden Aspektsystems darstellt. Frühere Berichte stimmen darin überein, dass sich die po-Delimitativen erst vor relativ kurzer Zeit verbreitet haben, so dass diese Entwicklung mit dem Verlust des Aorist-Tempus nicht verbunden sein können, der auch delimitative Werten mit atelischen Verben aufwies. Unter Verwendung von Baumbankdaten aus dem «Tromsø Old Russian and OCS Treebank», angereichert mit Tags für Ableitungsmorphologie und -semantik, zeige ich, dass die po-Delimitativen, selbst in den frühesten slawischen Quellen, weder in Bezug auf Häufigkeit noch Semantik marginal waren, und dass sie die Aorist-Delimitativen zuerst ergänzten und danach damit konkurrierten. Es 
kann also behauptet werden, dass die exotischen po-Delimitativen organisch aus dem alten indoeuropäischen Inflexionsaspektsystem herauswuchsen.

Keywords: aspect, delimitative, Slavic, prefixation

\section{Introduction}

The rise of the Russian po delimitatives ${ }^{1}$ is seen as crucial in most diachronic accounts of Russian aspect. In the earliest East Slavic texts, such as the Kievan Primary Chronicle, we find a situation where many of the features of the modern Slavic aspect system are in place: verbs have a strong tendency to pair up or group into triplets or even larger clusters, where prefixed underived verbs are telic and strongly associated with a perfective-like behaviour, while suffix-derived verbs are strongly associated with an imperfective-like behaviour (e.g. Růžička 1957, Forsyth 1972, Mišina 2017). This is also the case in Old Church Slavonic (OCS), the earliest attestation of Slavic (e.g. Dostál 1954, Amse-De Jong 1974, Eckhoff \& Haug 2015). However, many simplex verbs still display behaviour associated with both the perfective and imperfective aspect. The rise of po changes this landscape by gradually becoming a general perfectiviser for atelic verbs. This has two important consequences: firstly, almost all verbs now get a partner, and the formerly neutral simplex verbs become clearly imperfective. Secondly, prefixal perfectives need no longer be telic: in many cases $p o$ perfectivises simplex verbs by adding a purely temporal boundary for the verb event, not a telos, since many of these verbs have no inherent, natural endpoint.

In the earliest East Slavic texts, as well as in OCS, we also see a still-functional (albeit remodeled) version of the old Indo-European inflectional aspect system. In the past-tense system the aorist and imperfect appear to express a viewpoint aspect distinction between perfective and imperfective, and in the participle system we see a similar distinction between so-called past and present participles. The nature and division of labour between the new affix-derivational and the old inflectional system is a hotly debated issue (see e.g. Meillet 1934, van Schooneveld 1951, Dostál 1954, Forsyth 1972, Amse-de Jong 1974, Bermel 1997 and many others). In this article I follow Eckhoff \& Haug 2015 in claiming that they both expressed viewpoint aspect.

In fact, in any account of early Slavic aspect, the inflectional aspectual forms serve as a large piece of the evidence when judging the semantics of individual verbs. Apparently perfective verbs rarely occur as imperfects and present participles, while apparently imperfective verbs rarely occur as aorists and past participles (see Eckhoff \& Haug 2015 for OCS data).

However, while all early prefixal perfectives are telic, the aorist happily combines with atelic verbs, yielding ingressive or delimitative readings. In the old system, there thus was an established way of encoding temporally bounded atelic events. A tempting hypothesis, then, is that the po prefix takes over one of the functions of the aorist, and that its frequency is boosted when the aorist is subsequently lost from the system.

\footnotetext{
${ }^{1}$ I use the term "delimitative" in a wide sense, covering all verb events that are temporally bounded, without a telos (similar to the use of the term "complexive" in the literature on Ancient Greek aspect). In the Slavistic literature the term is (for good reasons) often reserved for temporally bounded events of short duration, while longer durations are referred to as "perdurative". In the history of Russian, it is clear that the po prefix gradually shifts to specialise with short-duration events (cf. Dickey 2007). This is clearly a topic that should be pursued, but which is beyond the scope of the current article (but see $\S 6$ on delimitative contexts in Old East Slavic). However, even in the late Middle Russian dataset, long-duration po delimitatives are still found.
} 
This article sets out to test whether this hypothesis is diachronically plausible. An immediate problem with the hypothesis is that the previous literature on the subject posits a relatively late date for the expansion of the po prefix (Dickey 2007, leaning on Sigalov 1975, Dmitrieva 2000). However, I shall argue that the empirical research for these studies was not sufficient, and that diachronic treebank data enriched with tags for inflectional morphology and semantics yields a different answer. The article thus also makes a case for the usefulness of enriched treebank data. The article is structured as follows. Section 2 briefly reviews the literature on the topic. Section 3 describes the data and methodology. Section 4 is an analysis of the diachronic development of po's semantics. Section 5 is a diachronic analysis of the verb classes found with delimitative aorists and delimitative po verbs. Section 6 uses syntactic data to compare the semantics of the delimitative aorist and delimitative $p o$ verbs in Old East Slavic. Section 7 is the conclusion.

\section{Previous approaches}

Dickey (2007) sees the rise and expansion of delimitative po as something of a mystery. In his view, which is supported by the previous literature, this function of the prefix was only marginally present in early historical times, and then sharply expanded as late as in the 17th century. He cites Němec (1954), who hypothesises that the original semantics of the po prefix encompassed both PATH, GOAL and SOURCE, i.e. all main spatial meanings related to motion along a trajectory. By historical times, Dickey (2007:332) claims, the predominant semantics is PATH, which was also extended to a surface-contact meaning (posmoliti 'cover with resin'), which tends to be telic since it often implies full coverage. The goal meaning of movement toward a landmark (postignuti 'reach') is also still around. The source meaning is largely gone, but is preserved in verbs that profile the inception of an in time (poiti 'go, set out'). The delimitative use, he concedes, had also appeared on the stage by historical times. Dickey sees it as a metaphorical extension of the PATH/SURFACE CONTACT sense of the prefix, from the spatial to the temporal domain. However, he concludes that this is a very small and semantically limited group of verbs.

Dickey (2007) did not do systematic empirical work himself, but bases his conclusions on empirical studies by Sigalov (1975) and Dmitrieva (1991, 2000). Sigalov 1975 claims that the early Slavic delimitatives, which were inherited from Common Slavic, comprised a very small class of what Dickey calls "basic stative activity predicates", i.e. statives and lowintensity activities. According to the statistics offered by Dmitrieva (1991) on the basis of dictionaries (which means that she is dealing in type frequencies, not token frequencies), the share of delimitatives among po verbs was very low in the Old East Slavic period: only $3.8 \%$ were delimitative, while as many as $73.5 \%$ were resultative. In Modern Russian she finds that $39.8 \%$ are delimitiative, ${ }^{2}$ while only $26 \%$ are resultative.

Sigalov (1975) suggests the following chronology for the expansion of the po delimitatives

1. Common Slavic: po delimitatives were statives

2. 16th-17th century: spread to indeterminate motion verbs and psychological processes

3. 17th-18th century: spread to speech verbs, sound emission verbs, physical processes

\footnotetext{
${ }^{2}$ As Dickey (2007) points out, given the extreme productivity of the delimitative po prefix in Modern Russian, 39.8\% must be considered a very conservative estimate of the overall share of delimitatives among po verbs, since many of them will not make it into the dictionaries.
} 
On the basis of these data and proposals, Dickey (2007) asks whether a few stative delimitatives could really have the power to make $p o$ verbs lose their resultative sense in favour of delimitativity. He concludes that they could not, and suggests that the late surge in productivity ${ }^{3}$ was due to a hyper-frequent model verb: the partial-ingressive poiti 'go, set out'. Dickey claims that this verb could only become a prototype for activities when it paired up with imperfective iti 'walk, go'. His story is thus that po went through a prototype shift triggered by a strong model verb.

However, Dickey does not look at competing ways of expressing delimitativity in early Slavic. As stated in the introduction, there was in fact an established way to express this meaning: atelic and aspectually neutral verbs could interact with the aorist to produce this reading (OCS: Eckhoff \& Haug 2015, Old East Slavic: Bermel 1995). As far as I am aware, the connection between the delimitative aorist and the delimitative po verbs has not been studied in the literature. It should be noted, though, that the aorist was lost by the 14th century. ${ }^{4}$ If the reported chronologies are correct, a direct causal relationship seems implausible.

The task of this article is therefore to examine the po delimitatives from the earliest attestations and up to the 17 th century, when the surge in productivity started, according to the previous literature.

\section{Data and method}

The data are taken from the Tromsø Old Russian and OCS Treebank (TOROT) (Eckhoff \& Berdičevskis 2015), a diachronic treebank of Russian which belongs to the PROIEL family of treebanks of early attestation of Indo-European languages (Haug \& Jøhndal 2008, Eckhoff et al. 2017). At the time of extraction, the treebank contained approximately 160,000 tokens of OCS with morphological and syntactic annotation ${ }^{5}$ (and a further 50,000 with morphological annotation and lemmatisation only), as well as approximately 230,000 tokens of Old East Slavic and Middle Russian with full morphological and syntactic annotation. The annotation follows the PROIEL dependency scheme, which is an enriched variant of dependency grammar designed to preserve as much linguistic detail as possible in the small, but complex historical text sources. In particular, the scheme includes secondary dependencies and empty verb and conjunction nodes to give detailed representations of control, agreement and ellipsis phenomena (see the introduction to this volume for more detail on treebank annotation styles).

\footnotetext{
${ }^{3}$ The term "productivity" has many possible definitions. In this paper a word-formation pattern will be considered the more productive the more lexemes are formed according to the pattern, and the less restricted the input lexeme is to particular semantic classes. For the delimitative $p o$ verb pattern, this means that the more delimitative po verbs we find, and the more semantic classes of base verbs are involved, the more productive the pattern is deemed to be.

${ }^{4}$ The precise date of the loss of the aorist in spoken Old East Slavic is much disputed. For a careful discussion of the problem, see Živov 2017:608-618.

${ }^{5}$ This includes the Codex Marianus, which is officially released by the PROIEL corpus at https://proiel.github.io/. This article also uses parallel data from the Greek Gospels, likewise taken from the PROIEL corpus. TOROT releases can be downloaded from http://torottreebank.github.io/.
} 
For the purposes of this article it is especially important to note that OCS, Old Russian and Old East Slavic verb lemmas have been tagged for derivational morphology: prefix, suffix and stem (for a further description of the tagging, see Eckhoff \& Haug 2015). These tags may be crossed with the detailed morphological tags for tense and mood/finiteness, and may be used to automatically classify verbs with great precision. In addition, semantic tags of various sorts were added to subsets of the data, as elaborated on further in the following sections.

\begin{tabular}{|l|l|l|}
\hline & Texts & $\begin{array}{l}\text { Number of extracted verbs } \\
\text { (excluding byti 'to be') }\end{array}$ \\
\hline OCS (with Greek parallel) & $\begin{array}{l}\text { Codex Marianus, Codex } \\
\text { Zographensis }\end{array}$ & 23,538 \\
\hline $\begin{array}{l}\text { Old East Slavic (11th-14th } \\
\text { century) }\end{array}$ & $\begin{array}{l}\text { Chronicles, Life of Boris } \\
\text { and Gleb, Life of Feodosij } \\
\text { Pečerskij, Russkaja pravda, } \\
\text { charters and treaties }\end{array}$ & 18,071 \\
\hline $\begin{array}{l}\text { Early Middle Russian (15th } \\
\text { century) }\end{array}$ & $\begin{array}{l}\text { Afanasij Nikitin, Tale of the } \\
\text { fall of Constantinople, Tale } \\
\text { of Luka Koločskij, Tale of } \\
\text { Dracula, Life of Sergij of } \\
\text { Radonež', charters }\end{array}$ & 6,240 \\
\hline $\begin{array}{l}\text { Late Middle Russian (16th- } \\
\text { 17th century) }\end{array}$ & $\begin{array}{l}\text { Tale of the taking of Pskov, } \\
\text { Domostroj, Life of Avvakum }\end{array}$ & 7,662 \\
\hline
\end{tabular}

Table 1. Overview of the four datasets ${ }^{7}$

\section{The semantic development of the po prefix}

The previous literature claims that the delimitative meaning was rare with the po prefix in the earliest sources, and that there was no sharp rise in the share of delimitatives until the 17th18 th century. To test this claim, I extracted all po verbs from my OCS, Old East Slavic, early Middle Russian and late Middle Russian datasets and classified them by their semantics. It should be noted that such classification must always be, to some extent, subjective, and that it is certainly possible to argue against some of my classifications. In particular, it was sometimes difficult to distinguish between delimitatives and ingressives. To give the reader full opportunity to do so, the classified dataset is published at doi:10.18710/PUXWXL.

The po verbs were tagged according to the following classification, adapted from Janda et al. (2013) and expanded with spatial semantics suggested in Dickey (2012). The classification is illustrated with OCS examples.

\footnotetext{
${ }^{6}$ The Primary Chronicle (Codex Laurentianus version in full, excerpts from the Codex Hypatianus version), excerpts from the First Novgorod Chronicle (Synodal manuscript), the Suzdal' Chronicle (Codex Laurentianus) and the Kiev Chronicle (Codex Hypatianus). For a full overview of the charters and treaties, see doi:10.18710/PUXWXL.

${ }^{7}$ The sizes of the four datasets directly reflect the bulk of texts per period in the TOROT at the time of data extraction. Since the two Middle Russian datasets are considerably smaller than the OCS and Old East Slavic ones, it is likely that we miss a number of individual po verbs that we might have captured, had the datasets been the same size. However, the relative type and token frequencies would probably not have differed much from what we see now.
} 
1. DELIMITATIVE: požbdati 'wait for a while' from žbdati 'wait', poiskati 'seek for a while' from iskati 'seek'

2. DISTRIBUTIVE: pobiti 'throw (a lot, used to describe stoning)' from biti 'beat', pozobati 'peck (up a certain amount of seeds)' from zobati 'peck'

3. GOAL: poxoditi 'go towards' from xoditi 'walk'

4. INGRESSIVE: pomilovati 'take pity on' from milovati 'pity, be merciful', pokajati se 'come to repent' from kajati se 'repent'

5. INGRESSIVE MOTION: povesti 'lead away' from vesti 'lead', posblati 'send (off)' from sblati 'send'

6. PATH: poslědbstvovati 'follow' from slědbstvovati 'follow'

7. RESULT: pogreti 'bury' from greti 'dig', posešti 'cut down' from sešti 'cut'

8. SEMELFACTIVE: pocělovati 'kiss once' from cělovati 'kiss'

8. SURFACE CONTACT: pomazati 'anoint, rub' from mazati 'rub', postblati 'spread out, lay out' from stblati 'spread, lay out'

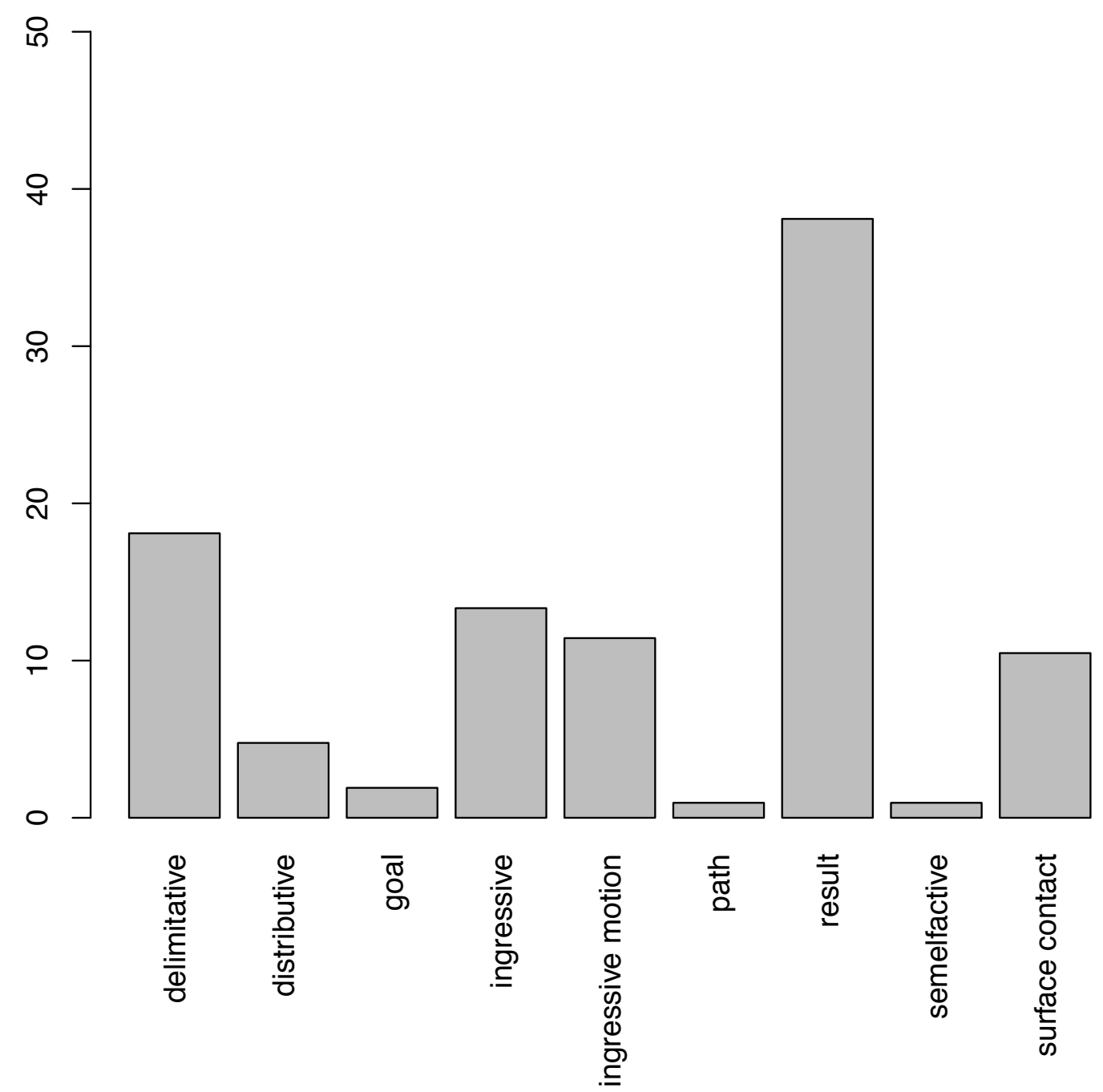


Figure 1. Semantic distribution of po verbs in OCS, predominant lemma meaning, ${ }^{8}$ per cent $(n=105)$

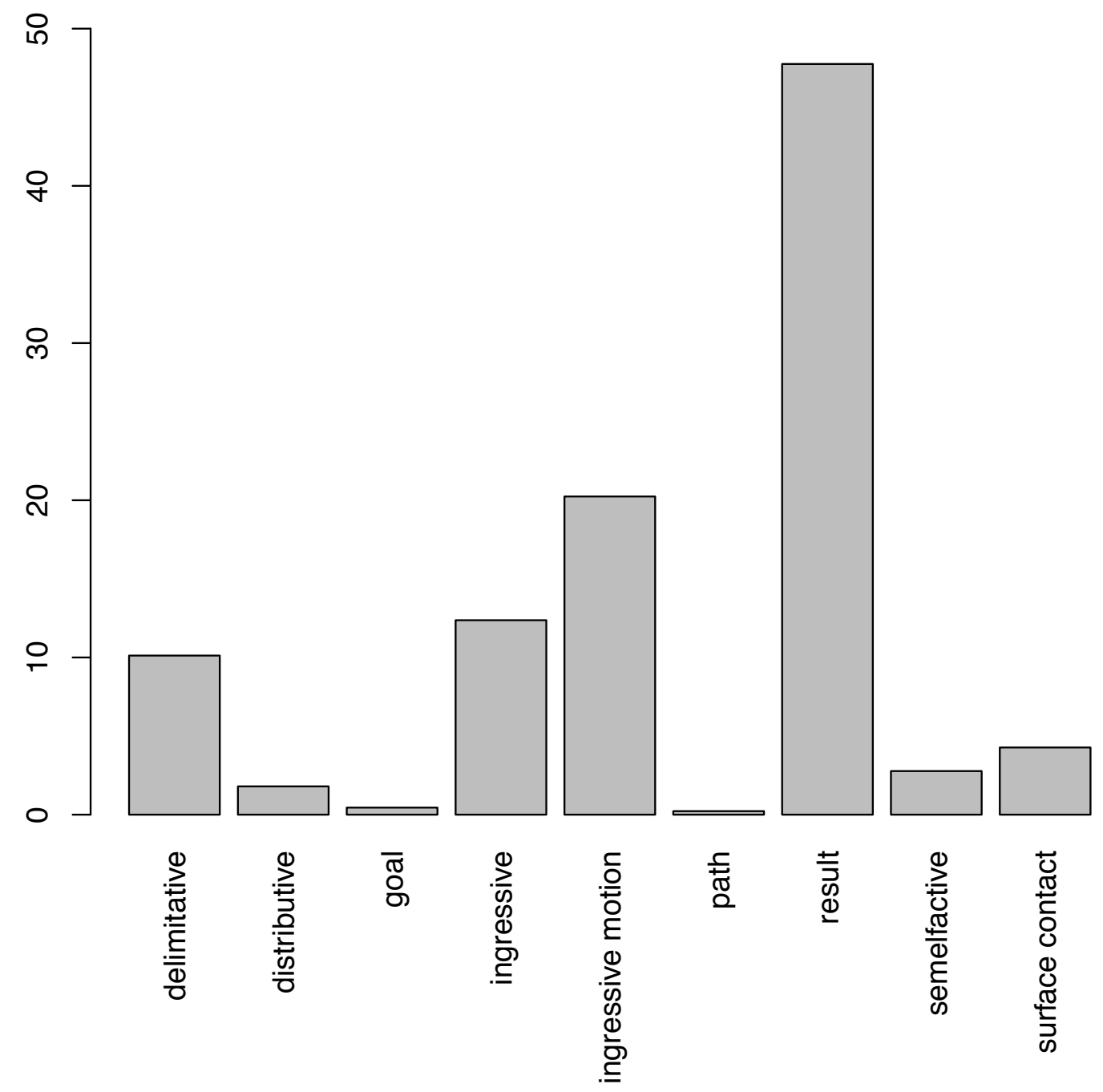

Figure 2. Semantic distribution of po verbs, tokens, per cent $(n=1334)$

The expectation from the literature is that delimitatives will be marginal in the semantic network of the OCS po verbs. However, we find that this is not the case - in fact, figure 1 shows that in terms of type frequency, the DELIMITATIVE meaning is the second most frequent among the po verbs (19 lemmas, 18\%), second only to RESULT (38\%). Figure 2 shows that it is less prominent in terms of token frequency, but hardly marginal at $10 \%$. The po verbs classified as delimitiative include požiti 'live', pomysliti 'think', poiskati 'seek' and poslužiti 'serve', among others. For a full breakdown of verb classes, see $\S 5$.

\footnotetext{
${ }^{8}$ The semantic tags were assigned to the lemmas by relative majority: the most frequent meaning among the lemma's tokens was assigned. The same method was used for the Old East Slavic/Middle Russian data.
} 


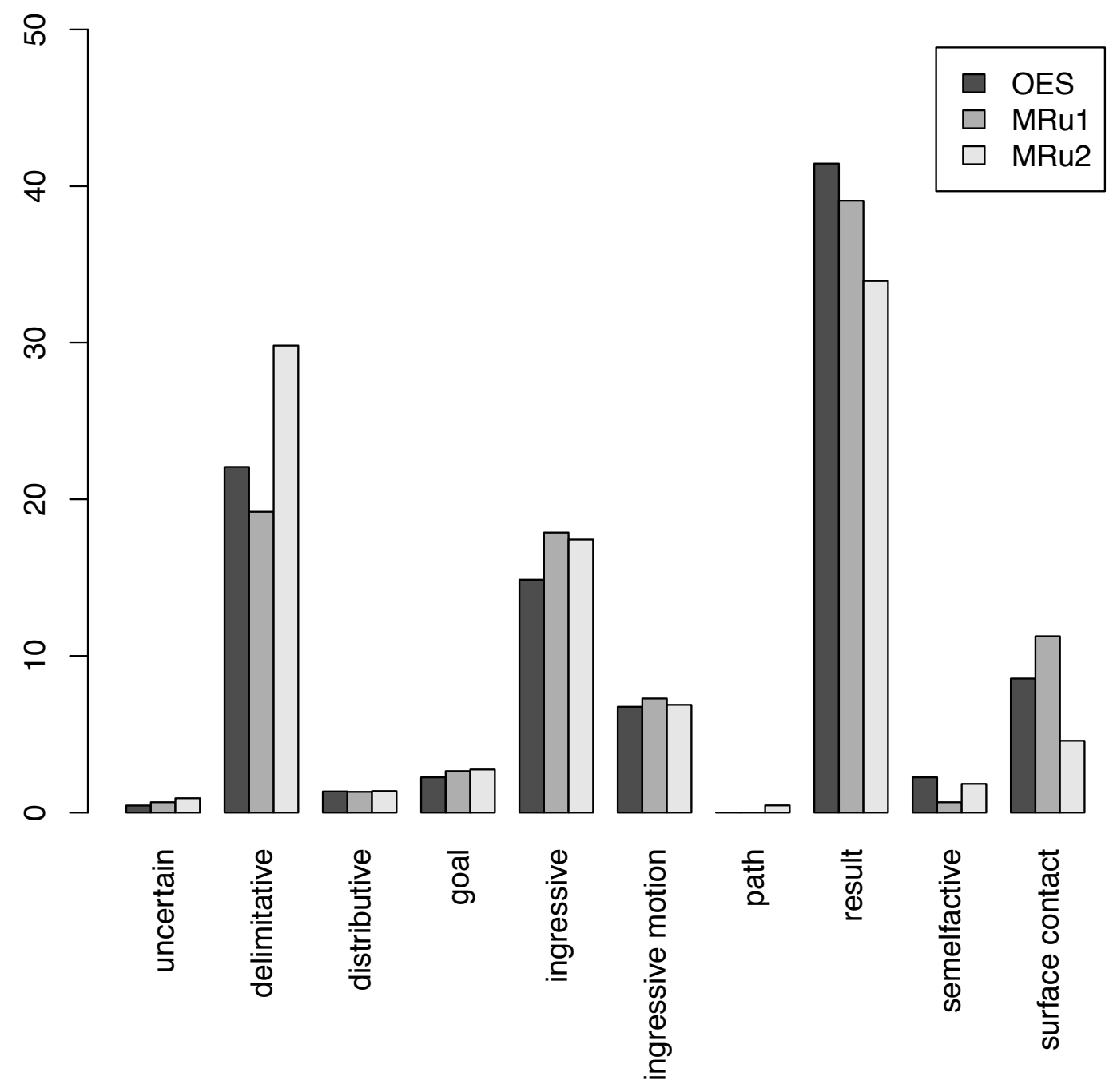

Figure 3. Po verb semantics in the history of Russian, predominant meaning of lemmas, per cent. OES = Old East Slavic, MRu1 = early Middle Russian, MRu2 = late Middle Russian 


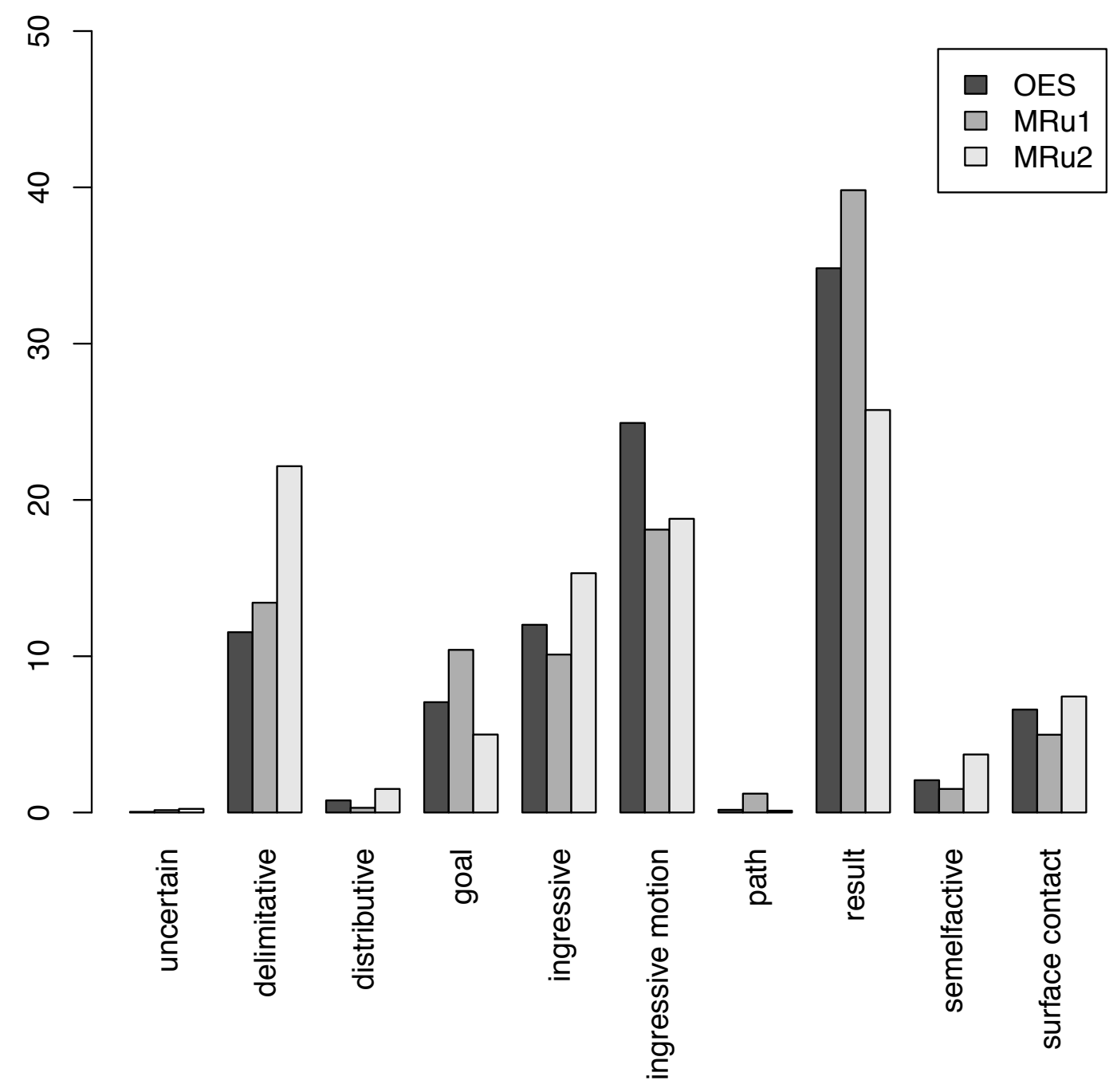

Figure 4. Po verb semantics 10th-17th century, tokens, per cent ${ }^{9}$

When we look at the Old East Slavic dataset (figures 3 and 4), we see a similar situation. The DELIMITATIVE meaning is not marginal in terms of frequency even in the earliest attestations. $22.1 \%$ of the po verbs (49 out of 222) are primarily DELIMITATIVE, including postojati 'stand', pojasti 'eat', poplakati 'cry' and počitati 'read'. For a full breakdown in verb classes, see §5. Looking at token frequencies, their share is somewhat lower, at $11.5 \%$ of all po verb attestations (268 out of 2323 occurrences) in the Old East Slavic dataset. However, both type and token frequency differ sharply from Dmitrieva's (1991) claim that the share of delimitatives was 3.8\% in her Old East Slavic material (cf. §2. The most frequent meaning among the po verbs is again RESULT - 41.4\% of all po lemmas in the Old East Slavic dataset have RESULT as their primary meaning, and $34.8 \%$ of the po verb tokens are used in a RESULT

\footnotetext{
${ }^{9}$ All po verbs with possible delimitative readings were manually counted. For all other verbs all tokens were deemed to have the predominant semantics of the verb lemma in question (i.e. the semantics of the relative majority of the tokens of that lemma).
} 
sense. Looking at the findings from OCS and Old East Slavic together, it is reasonable to claim that the DELIMITATIVE meaning was never marginal to $p o$ in attested times.

When we look at the diachronic development in type and token frequency (figures 2 and 3), we do find a significant increase ${ }^{10}$ in late Middle Russian (as expected from Sigalov 1975 and Dickey 2007). The increase is not very sharp, and the RESULT meaning is the most frequent in all periods, though the DELIMITATIVE meaning is catching up in late Middle Russian.

All in all, in terms of frequency, the 17th century development is not as radical as one might think from the literature.

\section{Aorists vs. po: Verb classes across time}

We have established that in terms of frequency, the DELIMITATIVE meaning was not marginal even in the earliest attestations of East Slavic or indeed Slavic overall (OCS). However, Sigalov 1975 and Dickey 2007 claim that the earliest po delimitative verbs are also semantically restricted, being limited to stative and low-intensity activity verbs. In this section I examine the verb classes found in delimitative $p o$ formations in all periods under scrutiny. ${ }^{11}$ For the OCS and Old East Slavic data sets, I also compare the distributions to those of the delimitative aorists. Thus I will be able to determine a) whether the early po delimitatives were really limited to a small semantically coherent group of verbs, and b) whether the same verbs and verb classes were found with both $p o$ delimitatives and delimitative aorists.

\footnotetext{
${ }^{10}$ Increase in type frequency from early to late Middle Russian: $p=0.0216$. Increase in token frequency from early to late Middle Russian: $\mathrm{p}<0.0001$. Fisher's exact test, two-tailed. ${ }^{11}$ The verb classes used are more granular than regular actionality class grids, for easy comparison with the previous literature.
} 


\subsection{OCS}

According to Sigalov (1975), ${ }^{12}$ the expectation is that OCS po delimitatives will be statives or low-intensity activities.

\begin{tabular}{|c|c|c|}
\hline & po delimitatives & $\begin{array}{l}\text { verbs occurring as } \\
\text { delimitative aorists }\end{array}$ \\
\hline $\begin{array}{l}\text { 1. States (including positional } \\
\text { verbs, but excluding psych } \\
\text { verbs) }\end{array}$ & požiti 'live', postradati 'suffer' & $\begin{array}{l}\text { bolèti 'be ill', běsbnovati } \\
\text { se 'be possessed by a } \\
\text { demon', žiti 'live', iměti } \\
\text { 'have', ležati 'lie', mošti } \\
\text { 'be able to', sédéti 'sit', } \\
\text { trěbovati 'need' }\end{array}$ \\
\hline 2. Plain activities & $\begin{array}{l}\text { pobbděti 'stay awake', } \\
\text { požbdati 'wait', poiskati } \\
\text { 'seek', pokaditi 'burn incense', } \\
\text { poslužiti 'serve', potrbpěti 'be } \\
\text { patient, endure', potręsti } \\
\text { 'shake' }\end{array}$ & $\begin{array}{l}\text { biti 'beat, hit', doiti } \\
\text { 'breastfeed', dělati 'do', } \\
\text { déjati 'do, work', krbstiti } \\
\text { 'baptise (in numbers)', } \\
\text { učiti 'teach', piti 'drink', } \\
\text { plakati 'cry', postiti 'fast', } \\
\text { rydati 'sob', sěti 'sow', } \\
\text { tvoriti 'do, make', jasti } \\
\text { 'eat' }\end{array}$ \\
\hline 3. Speech verbs & $\begin{array}{l}\text { pomoliti 'pray', ponositi } \\
\text { 'rebuke, insult', porogati } \\
\text { 'mock', poxvaliti 'praise' }\end{array}$ & moliti ‘pray’, \\
\hline 4. Psych verbs & pomysliti 'think' & $\begin{array}{l}\text { věděti 'know', věrovati } \\
\text { 'believe', mbněti 'think, } \\
\text { consider', xotěti 'want', } \\
\text { čisti 'honour' }\end{array}$ \\
\hline 5. Motion verbs & ponesti 'carry for a while' & \\
\hline 6. Secondary derived verbs & $\begin{array}{l}\text { podvižati 'move', pokyvati } \\
\text { 'nod', pomavati 'wave, make a } \\
\text { gesture', pomyšljati 'think' }\end{array}$ & \\
\hline
\end{tabular}

Table 2. Verb classes of po delimitatives and verbs attested as delimitative aorists / past participles in the OCS dataset

However, when we look at the occurrences in the dataset (table 2), only two of the 19 delimitative po verbs are arguably stative: požiti 'live' and postradati 'suffer' (tentatively applying the stativity tests in Lakoff 1966, Dowty 1979). The largest group of verbs consists of plain activities - some of them are low-intensity, such as požbdati 'wait' and potrbpěti 'be patient, endure', but most of them are not, such as poiskati 'seek' and poslužiti 'serve'.

(He will gird himself, and have them recline at the table)

\footnotetext{
${ }^{12}$ Sigalov takes his data from the file card index of the Slovar' drevnerusskogo jazyka XI$X V I I v v$ (Institut russkogo jazyka) and also excerpts from the following texts: Povest' vremennyx let (Laurentian Codex), First Novgorod Chronicle (Synodal manuscript), Izbornik 1076 goda, Gramotki XVII-nač. XVII goda (Moscow 1969) and Pamjatniki russkogo narodno-razgovornogo jazyka XVII stoletija (Moscow 1965). It is not clear whether the analysis of the excerpts from the sources have been done in a systematic manner.
} 
(1)

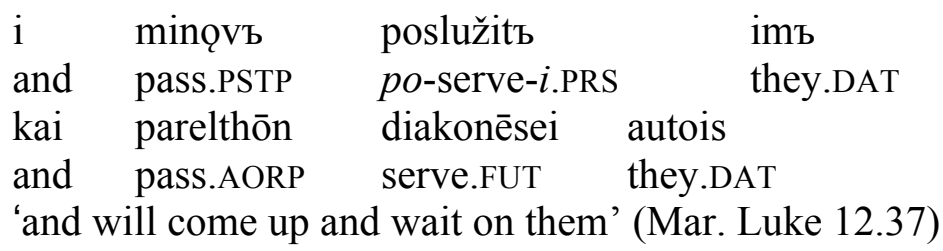

(2)

$\begin{array}{lllll}\text { poištete } & \text { mene } & \text { i } & \text { ne } & \text { obręštete } \\ \text { po-seek.PRS } & \text { me } & \text { and not find.PRS } \\ \text { zētēsete } & \text { me } & \text { kai oukh heurēsete } \\ \text { seek.FUT } & \text { me } & \text { and not ind.FUT } \\ \text { 'you will look for me but will not find me' (Mar. John 7.34) }\end{array}$

Sigalov (1975:161-162) argues for both these verbs that they are resultative in his Old East Slavic sources, but examples (1) and (2) show their use in contexts with no result, where the limitation is purely temporal - in example (1) the master will wait on his servants for the duration of the meal, and in example (2) it is explicitly stated that even though the disciples will look for Jesus for a while, the search will have no result. ${ }^{13}$

In addition to the "plain" activities, there are also speech verbs (or more precisely activities that involve speech), such as pomoliti 'pray', a psych verb (pomysliti 'think') and a motion verb (ponesti 'carry'). ${ }^{14}$

Finally, there are four verbs that are po-prefixed, but also have a secondary derivational suffix. These verbs are not always easy to interpret, but appear at least to some extent to be delimitative and iterative, i.e. the verb describes several temporally bounded bouts of nodding, waving, thinking etc. In example (3), there are as many delimited head-wagging events as there are passers-by.

\begin{tabular}{|c|c|c|c|c|c|}
\hline $\begin{array}{l}\text { i } \\
\text { and } \\
\text { pokyv } \\
\text { po-no }\end{array}$ & $\begin{array}{l}\text { mimo } \\
\text { by } \\
\text { ajǫšste } \\
\text { l-va.PRS }\end{array}$ & $\begin{array}{l}\text { xodęštei } \\
\text { passing-i.PRSP.NOM } \\
\text { glavami } \\
\text { heads.INST }\end{array}$ & $\begin{array}{l}\text { xulěaxQ } \\
\text { insult-i.IMPERF } \\
\text { svoimi } \\
\text { their.INST }\end{array}$ & $\begin{array}{l}\text { i. } \\
\text { he.ACC }\end{array}$ & $\begin{array}{l}\mathrm{i} \\
\text { and }\end{array}$ \\
\hline $\begin{array}{l}\text { kai } \\
\text { and }\end{array}$ & $\begin{array}{l}\text { hoi } \\
\text { the }\end{array}$ & $\begin{array}{l}\text { paraporeuomenoi } \\
\text { pass-by.PRSP.NOM }\end{array}$ & $\begin{array}{l}\text { eblasphēmoun } \\
\text { insult.IMPERF }\end{array}$ & $\begin{array}{l}\text { auton } \\
\text { he.ACC }\end{array}$ & $\begin{array}{l}\text { kinountes } \\
\text { move.PRSP }\end{array}$ \\
\hline $\begin{array}{l}\text { tas } \\
\text { the }\end{array}$ & $\begin{array}{l}\text { kephals } \\
\text { heads.A }\end{array}$ & $\begin{array}{ll}\text { as } & \text { autōn } \\
\text { ACC } & \text { their }\end{array}$ & & & \\
\hline
\end{tabular}

All in all, while OCS po delimitatives are not very frequent, they are certainly not limited to statives, in fact there are model verbs in all the most common atelic verb classes.

There are several interesting things to be noted about the TAM distribution of the OCS delimitative po verbs and their relationship to their Greek source forms (table 2). We can start

\footnotetext{
${ }^{13}$ Example (2) might also be read with a SURFACE CONTACT meaning: 'you will search all over the place', but if so, it would be a good bridging context for the purely temporal delimitatives.

${ }^{14}$ Technically, ponositi 'rebuke, insult' is the indeterminate variant of ponesti 'carry', but since it never occurs in its literal meaning in the dataset, it was classified among the speech verbs.
} 
by noting that generally, and even in OCS TAM forms that are not aspectual in themselves (boldfaced in table 3), the po verbs strongly tend to correspond to Greek perfective (aorist) forms. OCS imperfects and present participles are imperfective inflectional forms (cf. Eckhoff \& Haug 2015), and also to a very large extent correspond to Greek imperfective forms.

However, when we look at what OCS verbs we are dealing with here, we find that they are all formally expected to be imperfective: they are either occurrences of ponositi 'rebuke, insult', which is technically (but not semantically) a prefixed indeterminate motion verb, or belong to the group of secondary derived po verbs (pokyvati 'nod', pomavati 'wave, make a gesture', pomyšljati 'think', see example 3 ). There is thus strong support for assuming that the po delimitatives are perfective unless they are suffix-derived, i.e. that they follow the most common pattern for prefixed OCS verbs.

\begin{tabular}{|c|c|c|c|c|}
\hline & & per cent & Greek predominant aspect & Greek tense/mood \\
\hline aorist & 24 & 17.5 & perfective $92 \%$ & $\begin{array}{l}\text { aorist } 92 \% \text {, perfect } \\
8 \%\end{array}$ \\
\hline imperative & 10 & 7.3 & perfective $80 \%$ & imperative $100 \%$ \\
\hline imperfect & 17 & 12.4 & imperfective $88 \%$ & $\begin{array}{l}\text { imperfect } 88 \% \text {, } \\
\text { aorist } 12 \%\end{array}$ \\
\hline infinitive & 23 & 16.8 & perfective $83 \%$ & $\begin{array}{l}\text { infinitive } 91 \% \text {, } \\
\text { subjunctive } 9 \%\end{array}$ \\
\hline past active participle & 5 & 3.6 & perfective $100 \%$ & participle $100 \%$ \\
\hline present & 37 & 27.0 & perfective $35 \%$ & $\begin{array}{l}\text { future } 35 \% \text {, } \\
\text { present } 30 \% \text {, } \\
\text { subjunctive } 27 \% \text {, } \\
\text { infinitive } 8 \%\end{array}$ \\
\hline $\begin{array}{l}\text { present active } \\
\text { participle }\end{array}$ & 10 & 7.3 & imperfective $100 \%$ & participle $100 \%$ \\
\hline supine & 11 & 8.0 & perfective $100 \%$ & infinitive $100 \%$ \\
\hline
\end{tabular}

Table 3. TAM distribution of OCS delimitative po verbs and their Greek correspondences. Greek perfect and future are counted as non-aspectual

However, the most interesting observation to be made is that the po delimitatives are most frequently found in the present tense. Only $30 \%$ of these correspond to Greek present-tense forms, and again we observe that these examples are occurrences that belong in the group of secondary derived po verbs - in fact they are all occurrences of pomyšljati 'think'.

The majority of the present-tense forms, however, correspond either to the Greek future tense (examples 1 and 2) or the Greek subjunctive (4). The occurrences that correspond to the Greek future tense look very much like the perfective future in modern Slavic languages. The occurrences that correspond to Greek aorist subjunctives are mostly found in purpose clauses with $d a$ 'so that' and donbdeže 'until', where the verb also has a future reference, the wishedfor outcome is in the future. Thus, these forms are also similar to modern perfective futures both in form and usage contexts.

(Then they brought him children)

\begin{tabular}{|c|c|c|c|c|c|c|}
\hline $\begin{array}{l}\text { da } \\
\text { that }\end{array}$ & $\begin{array}{l}\text { rọcě } \\
\text { hand.ACC.DU }\end{array}$ & $\begin{array}{l}\text { vъzložitъ } \\
\text { vbz-lay-i.PRS }\end{array}$ & $\begin{array}{l}\text { na } \\
\text { on }\end{array}$ & $\begin{array}{l}\text { nę } \\
\text { they.ACC }\end{array}$ & $\begin{array}{l}\mathrm{i} \\
\text { and }\end{array}$ & $\begin{array}{l}\text { pomolitъ } \\
\text { po-pray-i.PRS }\end{array}$ \\
\hline $\begin{array}{l}\text { hina } \\
\text { that }\end{array}$ & $\begin{array}{ll}\text { tas } & \text { kheiras } \\
\text { the hands. }\end{array}$ & ACC $\quad$ put-upeit & & & & $\begin{array}{l}\text { kai } \\
\text { and }\end{array}$ \\
\hline
\end{tabular}


proseuxētai

pray.AOR.SUBJ

'(Then children were brought to him) that he might lay his hands on them and pray.' (Mar. Matt 19.13)

There are also a few temporal clauses with egda 'whenever', but in all of these cases the chosen verb is ponositi 'rebuke, insult', which formally looks like a derived imperfective verb, which suits the iterative nature of the context.

All in all, while the po delimitatives do occur in the perfective inflectional forms aorist and past participle, they seem to be particularly useful in cases when Greek uses a perfective form or a future, and OCS has no corresponding inflectional form to cover that particular meaning.

Let us now turn to delimitative atelic aorists in OCS. To find these, I selected all simplex verb lemmas that did not have a clear preference for a particular inflectional aspect, as well as verbs with a preference for the imperfective inflectional aspect, but which also had aorist/past participle occurrences. I found that 27 simplex verb lemmas (145 tokens) occur in the aorist or as past participles with a delimitative meaning (for the full dataset, see

doi:10.18710/PUXWXL, cf. Eckhoff \& Haug 2015). In example (5), we have a description of a situation that no longer obtains: Jesus lay in his grave for a certain period of time, but now he is no longer there. The aorist adds a temporal boundary to the simplex positional verb ležati 'lie'.

$$
\begin{array}{llll}
\text { vidita } & \text { město. } & \text { ideže leža } & \text { Хъ } \\
\text { see } & \text { place.ACC } & \text { where lie- } a . A O R & \text { Christ.NOM } \\
\text { deute } & \text { idete } & \text { ton topon } & \text { hopou ekeito } \\
\text { come } & \text { see.AOR.IMP } & \text { the place.ACC } & \text { where lie.IMPERF } \\
\text { 'Come, see the place } & \text { where He lay.' (Mar. Matt. 28.6) }
\end{array}
$$

The 27 simplex verbs can be seen in table 2 . The majority of the verbs are plain activities (such as délati 'do', učiti 'teach', plakati 'cry'), but there are also a number of stative verbs, including several positional verbs (žiti 'live', iměti 'have', ležati 'lie', mošt i 'be able to', sěděti 'sit'). There are also psych verbs (věděti 'know', věrovati 'believe') and a single speech verb (moliti 'pray'). All in all, we see that the verbs belong to the same verb classes as the po delimitatives, but there are only two overlaps: žiti 'live' and moliti 'pray'. This is illustrated in examples (6) and (7). In (6) we again see a present-tense po verb translating a Greek futuretense form. A reasonable interpretation might be 'Man will not live out his lifespan on bread alone'. In (7), on the other hand, we see a past participle of the simplex žiti 'live' occur with an explicit temporal delimitation, namely "seven years".

\begin{tabular}{lllllll} 
ne & o & xlěbě & edinomb & poživetъ & \multicolumn{2}{c}{ čkъ } \\
not & by & bread.LOC & alone.LOC & po-live.PRS & man.NOM \\
ouk & ep' & artōi & monōi & zēsetai & ho & anthrōpos \\
not & on & bread.DAT & alone.DAT & live.FUT & the & man.NOM
\end{tabular}

(She was advanced in years)

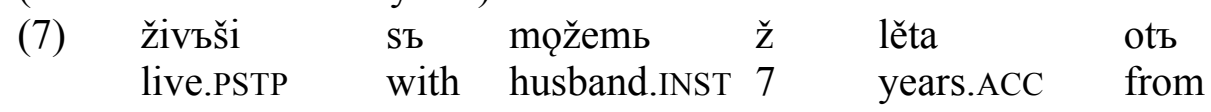




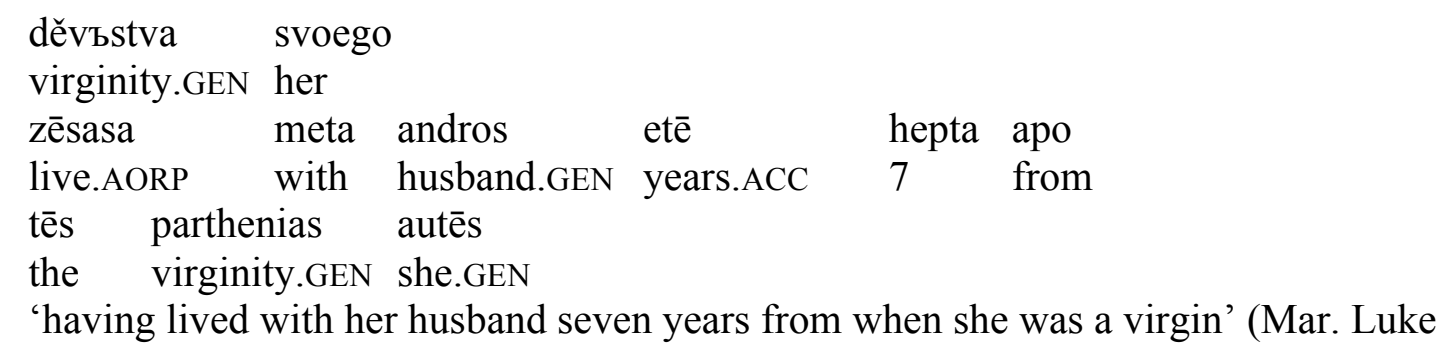

All in all, we see that both $p o$ verbs and delimitative aorists/past participles appear to be regular ways of expressing delimitativity in OCS. The inflectional way of expressing temporal boundaries on atelic verbs is thus limited to the past-tense and participle system, while the po verbs are available in all TAM forms. We see that the po verbs are particularly frequent in the present tense, rendering Greek futures and aorist subjunctives. While the delimitative $p o$ verbs and the verbs occurring as delimitative aorists belong to the same verb classes, the distribution is a bit different, and there are only two directly overlapping verbs. We may perhaps speculate that there was a division of labour between po and the aorist, both in the range of verbs and in the choice of TAM forms.

\subsection{Old East Slavic}

The Old East Slavic dataset is fairly similar to the OCS dataset in several respects: there are both po delimitatives and delimitative aorists, so the two are still in competition. The share of delimitatives among the po verbs is not significantly larger than what we found in the OCS dataset: $22.4 \%$ (50) of the po verbs are primarily delimitative (figure 3), and there are 56 po verbs that have at least one delimitative occurrence.

\begin{tabular}{|c|c|c|}
\hline & po delimitatives & $\begin{array}{l}\text { verbs occurring as } \\
\text { delimitative aorists }\end{array}$ \\
\hline $\begin{array}{l}\text { 1. States (including positional } \\
\text { verbs, but excluding psych } \\
\text { verbs) }\end{array}$ & $\begin{array}{l}\text { požiti 'live', poležati 'lie', } \\
\text { posvětiti 'shine', postojati } \\
\text { 'stand', postradati 'suffer', } \\
\text { posěděti 'sit' }\end{array}$ & $\begin{array}{l}\text { alıkati 'hunger', bolěti 'be } \\
\text { ill', vladěti 'rule', žiti 'live', } \\
\text { iméti 'have', kbnjažiti 'reign', } \\
\text { ležati 'lie', stojati 'stand', } \\
\text { sěděti 'sit', cěsarbstvovati } \\
\text { 'reign' }\end{array}$ \\
\hline 2. Plain activities & $\begin{array}{l}\text { pobljusti 'take care of', } \\
\text { povoevati 'wage war', } \\
\text { podvignuti 'move', požsdati } \\
\text { 'wait', pozorovati 'watch, } \\
\text { guard', pomuditi 'wait', } \\
\text { pombdliti 'wait, slow down', } \\
\text { pooxritati 'sneer at', } \\
\text { poplakati 'cry', poprijati 'be } \\
\text { friendly', poskrbgztati 'grind } \\
\text { (teeth)', poslužiti 'serve', } \\
\text { posměxati sja 'laugh at, } \\
\text { ridicule', posméjati sja } \\
\text { 'laugh', poszpati 'sleep', } \\
\text { potruditi 'work', potrjasti sja } \\
\text { 'shake', potbrpěti 'endure', }\end{array}$ & $\begin{array}{l}\text { biti sja 'fight', vojevati 'wage } \\
\text { war', dbržati 'hold', taiti } \\
\text { 'hide', ̌̌bdati 'wait', iskati } \\
\text { 'seek', kopati 'dig', metati } \\
\text { 'throw', mučiti 'torture', } \\
\text { plakati 'cry', prazdbnovati } \\
\text { 'celebrate', rabotati 'serve', } \\
\text { tvoriti 'do', truditi 'work', } \\
\text { trjasti 'shake', jasti 'eat' }\end{array}$ \\
\hline
\end{tabular}




\begin{tabular}{|c|c|c|}
\hline & $\begin{array}{l}\text { potjagnuti 'pull through', } \\
\text { poučiti 'teach, instruct', } \\
\text { počitati 'read', počrěti } \\
\text { 'scoop, draw', poščupati 'feel } \\
\text { for, pinch', pojasti 'eat' }\end{array}$ & \\
\hline 3. Speech verbs & $\begin{array}{l}\text { požalovati 'complain, express } \\
\text { pity', pomoliti 'pray', } \\
\text { ponositi 'reproach', porugati } \\
\text { 'scold', poxvaliti 'praise', } \\
\text { poxuliti 'condemn, deplore' }\end{array}$ & $\begin{array}{l}\text { besédovati 'talk', zъvati } \\
\text { 'call', moliti 'pray', } \\
\text { proročbstvovati 'prophesy' }\end{array}$ \\
\hline 4. Sound emission verbs & $\begin{array}{l}\text { pogrbméti 'thunder', } \\
\text { potrztati 'thunder' }\end{array}$ & pěti 'sing' \\
\hline 5. Psych verbs & $\begin{array}{l}\text { podivovati sja 'wonder, } \\
\text { admire', pokajati sja 'regret', } \\
\text { pomysliti 'think', popeči sja } \\
\text { 'care about', poskbrběti } \\
\text { 'grieve', postyditi sja 'be } \\
\text { ashamed of' }\end{array}$ & $\begin{array}{l}\text { věděti 'know', dumati } \\
\text { 'think', mošči 'be able to', } \\
\text { mbněti 'believe', xotéti } \\
\text { 'want', čuditi sja 'wonder' }\end{array}$ \\
\hline 6. Perception verbs & $\begin{array}{l}\text { pozbrěti 'look at', poslušati } \\
\text { 'listen to, obey' }\end{array}$ & $\begin{array}{l}\text { zbrěti 'look at', sbmotriti } \\
\text { 'look at' }\end{array}$ \\
\hline 7. Motion verbs & $\begin{array}{l}\text { poxoditi 'walk', poězditi } \\
\text { 'travel' }\end{array}$ & $\begin{array}{l}\text { broditi 'wander, wade', } \\
\text { vlačiti 'pull', goniti 'chase', } \\
\text { gznati 'chase', letěti 'fly', } \\
\text { ristati 'run', xoditi 'walk', } \\
\text { Šbstvovati 'walk, wander', } \\
\text { éxati 'drive, ride' }\end{array}$ \\
\hline 8. Secondary derived verbs & $\begin{array}{l}\text { pobarati 'fight', pokrapljati } \\
\text { 'sprinkle', pomavati 'wave', } \\
\text { pomyšljati 'think', posypati } \\
\text { 'sprinkle', poučati 'teach, } \\
\text { instruct', pouščati 'incite, } \\
\text { encourage', počrěpati 'scoop, } \\
\text { draw' }\end{array}$ & - \\
\hline
\end{tabular}

Table 4. Verb classes of delimitative po verbs and verbs occuring as delimitative aorists in the Old East Slavic dataset

As we see in table (4), the distribution of delimitative $p o$ verbs is not what we expect from Sigalov (1975)'s description: most of these verbs are dynamic, and the main bulk of verbs are normal-intensity activities, such as povoevati 'wage war', potruditi 'work', poslužiti 'serve' (8).

(The sinner observes the righteous man.)

$\begin{array}{llllll}\text { (8) } \mathrm{i} \quad \text { poskregčets na nb } & \text { zuby } & \text { svoimi } \\ \text { and po-grind.PRS on } & \text { he.ACC } & \text { teeth.INST } & \text { his.INST } \\ & \text { 'and grinds his teeth at him' (PVL 241.34) } & & \end{array}$

No more than five stative verbs (including positional verbs, but excluding psych verbs) were found in the dataset. As in the OCS dataset, there are speech, psych and motion verbs, but there are also sound emission and perception verbs. As in the OCS dataset, we also find suffix-derived po verbs which appear to be both delimitative and iterative (9). 


$\begin{array}{llllll}\text { mnogašbdy } & \text { že } \quad \text { i } & \text { prozvuterъ mltvu } & \text { tvoritь } & \text { i } \\ \text { frequently } & \text { PTC even } & \text { priest.NOM prayer.ACC } & \text { do-i.PRS } & \text { and } \\ \text { vodoju } & \text { stoju } & \text { pokrapljaja } & & & \\ \text { water.INST } & \text { holy.INST } & \text { po-sprinkle.PRSP } & & \end{array}$

'Many times the priest had already prayed and sprinkled holy water (but all in vain)' (Life of Feodosij Pečerskij, folio 54b)

The findings in the Old East Slavic dataset contradict the chronology proposed by Sigalov 1975: he claims that po delimitatives spread to indeterminate motion verbs and psychological processes in the 16th-17th century, and to speech verbs, sound emission verbs and physical processes in the 17th-18th century. However, all of these classes are already well represented in the Old East Slavic dataset.

When we compare with the OCS dataset, we see that the TAM distribution of po delimitatives is different. As we see in table 5, there is no preference for present tense anymore, the most common tense is now the aorist $(29.7 \%)$, followed by past participles $(17.1 \%)$, i.e. forms that are presumably also inflectionally perfective.

\begin{tabular}{|l|l|l|}
\hline TAM form & & per cent \\
\hline aorist & 80 & 29.7 \\
\hline imperative & 32 & 11.9 \\
\hline imperfect & 16 & 5.9 \\
\hline infinitive & 24 & 8.9 \\
\hline past participle & 46 & 17.1 \\
\hline present & 43 & 16.0 \\
\hline present participle & 16 & 5.9 \\
\hline l-form & 11 & 4.1 \\
\hline
\end{tabular}

Table 5. TAM distribution of Old East Slavic delimitative $p o$ verbs

As in OCS, Old East Slavic aorists have the potential for a delimitative (and ingressive) interpretation with atelic verbs (cf. Bermel 1995:340-341). I shall argue that the same holds for past active participles (but have found no examples of past passive participles with this reading in my dataset, and so make no claims about them).

To find these delimitative aorists and participles, Old East Slavic data can be sorted according to inflectional aspect in the same way as OCS. The tendency for overtly aspectually marked verbs to stick to the corresponding inflectional aspect is less clear than in the OCS dataset, but the method is still useful to find simplex verbs (i.e. verbs without prefixes and/or aspectual derivation suffixes) that are neutral or predominantly imperfective. In the Old East Slavic dataset, 47 neutral simplex verbs occur in the aorist or as a past participle with a delimitative reading (180 occurrences). ${ }^{15}$

The delimitative aorists and past participles are thus fairly common in the Old East Slavic dataset, and often occur in contexts that make the temporal boundary on the verb explicit, such as (9) and (10).

${ }^{15}$ The full classified dataset can be found at doi:10.18710/PUXWXL. 
trudixom sja i ne moguče sja dokopati

work-i.AOR REFL and not being-able REFL finish-digging

'We worked and couldn't finish digging' (PVL 210.6-7)

$(10)$
ždaša za měsjacb
wait- $a$.AOR for month
'they waited for a month (but he didn't pay them)' (PVL 79.1)

When we look at the verb classes of the simplex verbs, we find all the same classes as with the Old East Slavic po delimitatives (table 4). ${ }^{16}$ There are statives such as bolěti 'be ill', žiti 'live', iméti 'have', activities such as iskati 'seek', kopati 'dig', plakati 'cry', speech, psych and perception verbs, and also a large number of motion verbs.

Recall that in the OCS dataset, the simplex aorist verbs had almost no overlap with the po delimitatives. In the Old East Slavic dataset, however, there are 13 overlapping verbs in multiple verb classes (boldfaced in table 4), such as žiti 'live', stojati 'stand', voevati 'wage war', plakati 'cry', moliti 'pray'. Recall also that while in the OCS dataset, po delimitatives had a preference for occurring in the present tense, they predominantly occur in the aorist in the Old East Slavic dataset. This means that in the Old East Slavic dataset, we observe a number of "minimal pairs", that is aorists with delimitative readings and the same base verb, differentiated only by the presence/absence of the po prefix. Examples (11) and (12) are very similar and describe temporally delimited waging-war events. However, only example (11) has the po prefix.

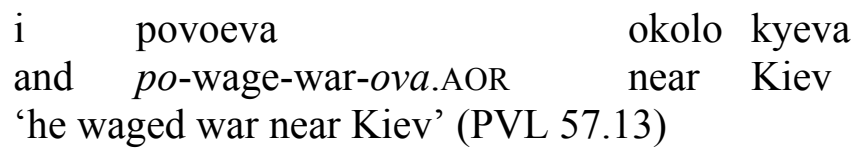

$\begin{array}{llll}\text { voevaša } & \text { polovci } & \text { okolo } & \text { zarěčsska } \\ \text { wage-war-ova.AOR } & \text { Polovecians } & \text { near } & \text { Zarečsk } \\ \text { 'The Polovecians waged war near Zarečsk' } & \text { (PVL 281.4) }\end{array}$

\subsection{Middle Russian}

The use of the delimitative aorist is nearly non-existent in the Middle Russian sources, and the very few potential examples should probably be treated as archaisms. In this section I therefore only look at the semantic classes of po verbs in the two Middle Russian datasets: early (15th century) and late (16th-17th century).

There is no significant increase either in type or token frequency for delimitative po verbs in the early Middle Russian dataset. A breakdown of the 29 attested delimitative po verbs into verb classes (table 6) shows us that the distribution across verb classes is also very similar to that found in the Old East Slavic dataset. However, we see 20 verbs that were not found in the (considerably larger) Old East Slavic dataset, suggesting that new verbs may nonetheless have joined the $p o$ verb pattern.

\begin{tabular}{|l|l|}
\hline 1. States (including positional verbs) & pobolět $i \dagger$ 'be ill', pobyti 'be', požiti*† 'live',
\end{tabular}

\footnotetext{
${ }^{16}$ Suffix-derived verbs were excluded by definition, though they do sometimes occur as aorists and past participles with delimitative-iterative readings.
} 


\begin{tabular}{|c|c|}
\hline & postradati* 'suffer' \\
\hline 2. Plain activities & $\begin{array}{l}\text { požbdati* 'wait', poiskati* 'seek', pokolěbati } \\
\text { sja 'waver', pokolébiti 'rock, shake', } \\
\text { porabotati 'work', poslužiti* 'serve', } \\
\text { potzlkati 'knock', potbrpěti* 'endure', } \\
\text { potjanuti 'pull', potrjasti sja*†' 'shake', } \\
\text { poučiti 'teach, instruct', počitati 'read' }\end{array}$ \\
\hline 3. Speech verbs & $\begin{array}{l}\text { pobesědovati } \uparrow \text { 'talk', pomoliti*† 'pray', } \\
\text { porugati* 'scold', poxvaliti* 'praise', } \\
\text { pošbpbtati 'whisper' }\end{array}$ \\
\hline 4. Sound emission verbs & postonati 'moan' \\
\hline 5. Psych verbs & pokajati sja 'regret', porasuditi 'consider' \\
\hline 6. Perception verbs & poslušati 'listen to, obey', posmotrěti † 'look' \\
\hline 7. Motion verbs & poiti 'walk, go ahead', ponesti 'carry, bear' \\
\hline 8. Secondary derived verbs & $\begin{array}{l}\text { pobivati 'beat', pokazovati 'display', } \\
\text { pominati 'remember', pomyšljati* 'think', } \\
\text { popolaskyvati 'rinse', posypati 'sprinkle', } \\
\text { poučati 'teach, instruct', poxvaljati 'praise', }\end{array}$ \\
\hline
\end{tabular}

Table 6. Verb classes of delimitative $p o$ verbs in early Middle Russian. Delimitative po verbs also found in the Old East Slavic dataset are boldfaced, the ones that were also found in the OCS dataset are marked with an asterisk. Verbs with a base verb that occurred as a delimitative aorist/past participle in the OES dataset are marked with a $\uparrow$

The late Middle Russian dataset is the first dataset where we see a significant increase in type and token frequency of delimitative po verbs, as shown in figures 2 and 3. In the late Middle Russian dataset, there are 71 po verbs with at least one delimitative occurrence. $30.4 \%$ of the po verbs are primarily delimitative.

When we look at the verb classes of the delimitative $p o$ verbs, we see that they are still the same as in Old East Slavic (table 7). There are also considerable overlaps in the attested verbs in all classes - all classes contain verbs that were attested with delimitative meanings in the Old East Slavic dataset as well (boldfaced), and sometimes also in the OCS dataset (marked with an asterisk).

\begin{tabular}{|c|c|}
\hline 1. States (including positional verbs) & $\begin{array}{l}\text { požiti*†' 'live', poležati† 'lie', pomblčati 'be } \\
\text { quiet', postojati† 'stand', postradati* } \\
\text { 'suffer', posěděti } \dagger \text { 'sit' }\end{array}$ \\
\hline 2. Plain activities & $\begin{array}{l}\text { pobljusti 'take care of', pogladiti 'stroke', } \\
\text { podvignuti 'move', podbržati† 'hold, retain', } \\
\text { požati 'squeeze', pozvoniti 'ring', pokaditi* } \\
\text { 'burn incense', pokolotiti 'knock', pokropiti } \\
\text { 'sprinkle', ponakazati 'teach', popaxati } \\
\text { 'plough', popoloskati 'rinse', poslužiti* } \\
\text { 'serve', postegati 'whip', potzlkati sja } \\
\text { 'knock', potruditi† 'work', potbrpěti* } \\
\text { 'endure', potjanuti 'pull', potrjasti sja*† } \\
\text { 'shake', poučiti 'teach, instruct', počitati } \\
\text { 'read', poščupati 'feel for, pinch', pojasti† } \\
\text { 'eat' }\end{array}$ \\
\hline
\end{tabular}




\begin{tabular}{|c|c|}
\hline 3. Speech verbs & $\begin{array}{l}\text { pobesědovati } \dagger \text { 'talk', poblagodariti 'thank', } \\
\text { pobraniti 'scold', pogovoriti 'talk', } \\
\text { požalovati 'forgive, endow', pomolitvovati } \\
\text { 'pray', pomoliti*†' 'pray', poricati 'reproach', } \\
\text { porugati*'scold', poslušbstvovati 'testify', } \\
\text { poxvaliti* 'praise', poxuliti 'condemn, } \\
\text { deplore' }\end{array}$ \\
\hline 4. Sound emission verbs & postonati 'moan' \\
\hline 5. Psych verbs & $\begin{array}{l}\text { podumatì 'think', požalěti 'pity', pokajati } \\
\text { sja 'regret', pomysliti* 'think', popeči sja } \\
\text { 'care about', poraděti 'care' }\end{array}$ \\
\hline 6. Perception verbs & $\begin{array}{l}\text { pogljaděti 'look', poslušati 'listen to, obey', } \\
\text { posmotrěti† 'look' }\end{array}$ \\
\hline 7. Motion verbs & popoiti 'go away for a bit', poxoditi $\uparrow$ 'walk' \\
\hline 8. Secondary derived verbs & $\begin{array}{l}\text { pobivati 'beat', pobirati 'gather', pobyvati } \\
\text { 'be', pověvati 'wave', pogljadyvati 'look', } \\
\text { pogovarivati 'talk', pomanivati 'coax, } \\
\text { entice', pomyšljati* 'think', ponašati 'scorn, } \\
\text { ridicule', poskakyvati 'jump, gallop', } \\
\text { poslušivati 'listen', posmatrivati 'look', } \\
\text { posypati 'sprinkle', potbčivati 'honour, } \\
\text { serve', poučati 'teach, instruct', poxvaljati } \\
\text { 'praise', poxlébati 'sip', poxuljati 'complain' }\end{array}$ \\
\hline
\end{tabular}

Table 7. Verb classes of delimitative $p o$ verbs in late Middle Russian. Delimitative $p o$ verbs also found in the Old East Slavic dataset are boldfaced, the ones that were also found in the OCS dataset are marked with an asterisk. Verbs with a base verb that occurred as a delimitative aorist/past participle in the OES dataset are marked with a $\uparrow^{17}$

$$
\begin{array}{ll}
\text { pomolčalı } & \text { malenko } \\
\text { po-be-quiet.PST } & \text { little } \\
\text { 'I was quiet for a while' (Life of Avvakum) }
\end{array}
$$

There are also 13 overlaps with the delimitative simplex aorists from the Old East Slavic (marked with $\dagger$ in table 5).

$$
\begin{aligned}
& \text { ašte kto potrudit sę } \mathrm{V} \text { semъ věce } \\
& \text { if someone po-work-i.PRS REFL in this age } \\
& \text { kingdom.GEN for heavenly.GEN } \\
& \text { '... if someone works in this age for the sake of the Kingdom of Heaven' (Domostroj) }
\end{aligned}
$$

Thus there is no evidence that any new verb classes have joined the po verb pattern, although it is likely that a number of individual verbs have, given the significant increase in the type frequency of delimitative po verbs. At least some of these (base) verbs have delimitative aorist / past participle attestations in the Old East Slavic dataset, but even more of them occurred in attested variation as early as in Old East Slavic.

${ }^{17}$ Table 6 only contains 70 verbs, the final one is the form postaja (Life of Avvakum folio $70 \mathrm{v}$ ), which has tentatively been lemmatised as postati, but is unclear. The delimitative semantics seem clear enough, though. 


\section{Delimitative contexts in Old East Slavic}

So far this paper has exclusively used lemmatisation, morphological annotation, semantic annotation and sub-word-level annotation of derivational morphology, i.e. annotation levels that are not reserved for treebanks. We can, however, use the treebank data directly to explore two closely related questions: Were delimitative aorists and po delimitatives really synonymous in Old East Slavic? And were there any competing means of expressing delimitativity? We can operationalise both of these questions by looking at the types of temporal adverbials that come with the two types of delimitatives, since they make explicit the temporal boundary placed on the event.

There were 180 occurrences of aorists or past participles classified as delimitative in the Old East Slavic dataset. 115 of them had an adverbial modifier of some sort. By far the largest group of temporal adverbials (41 examples) were temporal accusatives indicating the (long) duration of the event, as in (15).

$$
\begin{aligned}
& \text { i leža noščs tu } \\
& \text { and lie- } a \text {.AOR night.ACC there } \\
& \text { "and [the corpse] lay there one night" (Suzdal Chronicle, year 6655) }
\end{aligned}
$$

Another sizeable group of temporal adverbials are $v b+$ acc constructions (11 examples), which generally serve as framesetters, and do not delimit the event directly, but typically also go with fairly long durations, as in (16).

$$
\begin{aligned}
& \mathrm{V} \text { seže vremja voeva kurja } \\
& \text { in the-same.ACC time.ACC wage-war-ova.AOR Kurya } \\
& \mathrm{s} \text { polovci } \mathrm{u} \text { perejaslavlja } \\
& \text { with Polovecians.INST by Perejaslavl'.GEN } \\
& \text { "In the same period Kurya and the Polovecians waged war near Perejaslavl"" (PVL }
\end{aligned}
$$

There are also five examples expressing long duration with mbnogo 'much, a lot', but only a single example explicitly expressing short duration with malo 'a little' (17).

$$
\begin{aligned}
& \text { (17) i bivъše } \quad \text { sja malo negde. } \\
& \text { and fight.PSTP } \\
& \text { na ostrově. } \\
& \text { on island.LOC } \\
& \text { "having fought a little at one point, the men of Novgorod took stand on an island" } \\
& \text { (First Novgorod Chronicle, year 6657) }
\end{aligned}
$$

Thus, it seems that the delimitative aorist/past participle was primarily used for fairly long durations, though short durations were also possible.

There are 253 occurrences of po delimitatives in the Old East Slavic dataset, and 105 of them have an adverbial of some type. We do find the same types of temporal adverbials as with delimitative aorists/past participles, but the distribution is quite different. Only four examples have temporal accusatives (18).
že $\quad$ v
ejuptě.
lět
.zi. 
po-live.AOR PTC in Egypt.LOC year.GEN.PL 17

"and he lived in Egypt for 17 years" (PVL 93.27)

There are also few temporal $v b+$ acc constructions, again, only four examples were found in the Old East Slavic dataset. The most frequent type of temporal adverbial turns out to be ones expressing short duration: there are 16 examples with the adverbial malo 'a little, for a short while' (19).

$$
\begin{array}{ll}
\text { posědi } & \text { malo } \\
\text { po-sit-ě.IMP2SG } & \text { little }
\end{array}
$$

'Sit for a little while!' (PVL 266.2)

Thus, even though both the delimitative aorist/past participle and the delimitative po verbs can denote both short and long durations, the distribution of overt duration adverbials suggests that they have different preferences: long durations for the aorists, and short durations for the $p o$ verbs.

Having identified the temporal accusative and short-duration adverbials such as malo as typical delimitative contexts, we can also use them to look for other types of verbs occurring in the same contexts. Do we find other verbs than atelic simplices and po verbs in the Old East Slavic dataset?

Short-duration adverbials of the malo type only very rarely occur with verbs that are neither po verbs nor atelic simplices. Only three examples were found, all three prefixed with either pere or its Church Slavonic counterpart prě, as in (20).

(He promised to go, but did not go.)

$\begin{array}{llll}\text { (20) } & \text { i perestrjapъ } & \text { malo poslušavъ } & \text { Žiroslava } \\ \text { and pere-linger.PSTP little po-hear-a.PSTP } & \text { Žiroslav.GEN } \\ \text { rekušča jemu } & & \\ \text { saying.GEN he.DAT } \\ \text { 'and having lingered a little, he heard Žiroslav saying to him' (Suzdal' Chronicle, year }\end{array}$

With the temporal accusative we find more examples of non-derived verbs with prefixes other than po (limited to contexts where the temporal accusative expresses true duration, omitting examples such as večer ' in the evening'). There are 16 examples of prě verbs, most of them occurrences of prěbyti 'stay (for some specified time)' (20), and one of perestrjati, which we saw in example (19). The prefix thus appears to be in some use to form perdurative verbs.

(20) i tako prebys vse lěto do zimy

and thus prě-be.aor all.acc summer.acc until winter.gen

'and thus he remained all summer until winter' (Suzdal' Chronicle, year 6635)

More intriguingly, the Old East Slavic dataset also contains two aorist examples of the verb $s b t v o r i t i$ 'do, perform', derived from the simplex tvoriti with the prefix $s b$. This prefix otherwise produces telic and apparently perfective verbs. In examples (21) and (22), however, it seems to take on a meaning close to that of the delimitative aorist.

$$
\text { vsju noščb moltvu stvoriša }
$$


all.acc night.acc prayer.acc sb-do-i.aor3pl

"they prayed all night" (PVL 21.20)

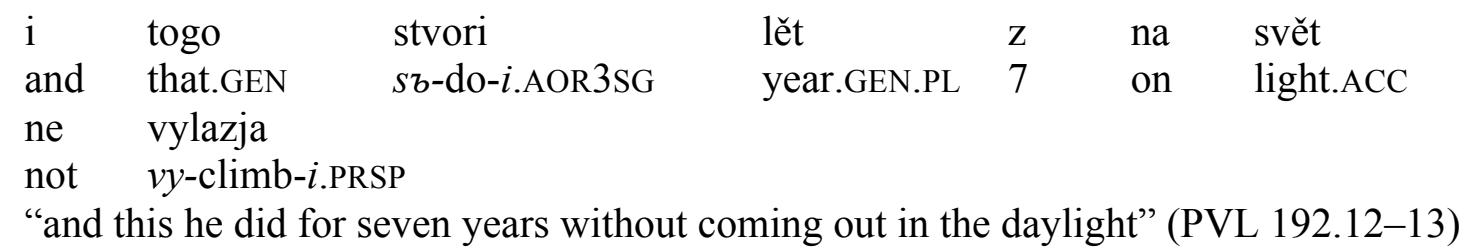

These examples suggest that po may have had some competition from $s b$, which was also a very productive and semantically general prefix.

\section{Conclusions}

This paper uses new enriched treebank data to revisit a central issue in the development of the modern Russian aspect system: the rise of the po delimitative. The paper exploits the fact that the PROIEL and TOROT treebanks are enriched with sub-word-level tagging for derivational morphology, and supplements the rich morphological annotation with semantic tagging, but also uses the syntactic tagging to look for delimitative contexts.

There is consensus in the literature that the rise of the po delimitative was an important step in generalising the aspect partner system in the history of Russian. When the po delimitative gained in productivity, a lot of atelic verbs could suddenly have perfective partners. It seems clear that this surge in productivity came relatively late, and the results of this paper support that conclusion. However, the treebank data does not support the common assumption that the po delimitatives were wholly marginal and severely semantically restricted until a very late stage: even in OCS and Old East Slavic, around 20\% of all po verb lemmas had delimitative readings, and these verbs were not restricted to statives, but belonged to all verb classes found with late Middle Russian po delimitatives.

The previous literature also fails to discuss the main competition of the po delimitatives in early Slavic: the delimitative usage of aorists and past participles with atelic simplex verbs, arguably the last independent function of the aorist, found both in OCS and Old East Slavic. Given earlier accounts, the chronology did not seem to match up. However, the treebank data turn out to support the hypothesis that the po delimitatives gradually took over this function from the inflectional aspect system. In the earliest sources we see a situation where verbs from largely the same verb classes may either occur as delimitative aorists / past participles, or form po delimitatives: both constructions could convert states and activities into delimitatives. Some verbs are attested in both constructions. There are more of these overlaps in the Old East Slavic dataset than in the OCS one. The TAM distribution of the po verbs is also different: in the OCS dataset we see that they predominantly occur in the present tense, while in the Old East Slavic dataset, they predominantly occur as aorists, yielding a larger number of "minimal pairs". This suggests a development from a division of labour to a situation of free variation. In Middle Russian the aorist is lost, and the po delimitatives are left to do the job on their own. Looking at the verb classes of the po verbs in the late Middle Russian dataset, we see that they are the same as the ones we found in OCS and Old East Slavic datasets, and that many of the verbs are also the same, or correspond to simplex verbs that could formerly occur as delimitative aorists or past participles.

It thus seems fair to say that the development of (productive) Russian po delimitatives was boosted by the loss of the delimitative aorist with simplex verbs, since, as outlined in $\S 6$, they 
coexisted for a considerable while with much the same functions, making the po verbs the natural heir of the aorist in this respect. In this sense it may be argued that the exotic Russian po delimitatives grew directly out of the old Indo-European aspect system.

\section{References}

Amse-De Jong, Tine H. 1974. The meaning of the finite verb forms in the Old Church Slavonic Codex Suprasliensis: A synchronic study. The Hague: Mouton.

Bermel, Neil. 1995. Aspect and the Shape of Action in Old Russian Author(s). Russian Linguistics 19(3). 333-348.

Bermel, Neil. 1997. Context and the lexicon in the development of Russian aspect (University of California Publications in Linguistics 129). Berkeley: University of California Press.

Dickey, Stephen M. 2007. A prototype account of the development of delimitative po- in Russian. In Dagmar Divjak \& Agata Kochanska (eds.), Cognitive paths into the Slavic domain. Berlin: Mouton DeGruyter. 326-371.

Dickey, Stephen. 2012. Orphan prefixes and the grammaticalization of aspect in South Slavic. Jezikoslovlje 13(1). 71-105.

Dmitrieva, Ol'ga. 1991. Formirovanie semantičeskoj struktury russkogo glagol'nogo prefiksa po-. In Aktivnye processy v jazyke i reči. Saratov: Izdatel'stvo Saratovskogo universiteta. 68-74.

Dmitrieva, Ol'ga. 2000. Formirovanie sistemy russkix delimitativnyx glagolov. In T. V. Kočetkova (ed.), Predloženie i slovo: paradigmatičeskij, tekstovyj i kommunikativnyj aspekty. Saratov: Izdatel'stvo Saratovskogo pedagogičeskogo instituta. 28-33.

Dostál, Antonin. 1954. Studie o vidovém systému v staroslověnštině. Prague: Státní pedagogické nakladatelství.

Dowty, David R. 1979. Word Meaning and Montague Grammar: The Semantics of Verbs and Times in Generative Semantics and in Montague's Ptq. Dordrecht: Reidel.

Eckhoff, Hanne Martine \& Aleksandrs Berdicevskis. 2015. Linguistics vs. digital editions: The Tromsø Old Russian and OCS Treebank. Scripta \& e-Scripta 14-15. 9-25.

Eckhoff, Hanne, Kristin Bech, Kristine Eide, Gerlof Bouma, Dag Haug, Odd Einar Haugen \& Marius Jøhndal. 2017. The PROIEL treebank family: a standard for early attestations of Indo-European languages. Language Resources and Evaluation (online first).

Forsyth, James. 1972. The nature and development of the aspectual opposition in the Russian verb. The Slavonic and East European Review 50(121). 493-506.

Haug, Dag Trygve Truslew \& Marius Jøhndal. 2008. Creating a parallel treebank of the old Indo-European Bible translations. In Caroline Sporleder \& Kiril Ribarov (eds.), Proceedings of the LaTeCH Workshop - LREC. 27-34. Marrakech: www.lrecconf.org/proceedings/ lrec2008/index.html

Janda, Laura A., Anna Endresen, Julia Kuznetsova, Olga Lyashevskaya, Anastasia Makarova, Anastasia, Tore Nesset \& Svetlana Sokolova. 2013. Why Russian Aspectual Prefixes Aren't Empty: Prefixes As Verb Classifiers. Bloomington: Slavica.

Lakoff, George. 1966. Stative Adjectives and Verbs in English. In Report NSF-17. Harvard Computation Lab.

Meillet, Antoine. 1934. Le slave commun. Paris: Champion.

Mišina, Ekaterina A. 2017. K izučeniju perfektivnogo imperfekta v drevnerusskom jazyke (v sopostavlenii so staroslavjanskim). Russian Linguistics 41(1). 1-15.

Němec, Igor. 1954. O slovanské předponě po- slovesné. Slavia 23. 1-22.

Růžička, Rudolf. 1957. Der Verbalaspekt in der altrussischen Nestorchronik

(Veröffentlichungen des Instituts für Slawistik 14). Berlin: Akademie-Verlag. 
Schooneveld, Cornelis H. van. 1951. The aspect system of the Old Church Slavonic and Old Russian verbum finitum byti. Word 7. 96-103.

Sigalov, Pavel S. 1975. Istorija russkix ograničitel'nyx glagolov. Trudy po russkoj $i$ slavjanskoj filologii: Serija lingvističeskaja 24. 141-181.

Živov, Viktor M. 2017. Istorija jazyka russkoj pis'mennosti. Vol. 1. Moscow: Universitet Dmitrija Požarskogo.

\section{Appendix}

The datasets for this study were extracted from the TOROT treebank using Ruby scripts accessing the database and webapp methods directly. Unfortunately, we have not yet been able to provide a similar way to draw detailed datasets of this type that is open to the public.

The basic query for all datasets is very simple. For the OCS study (which recycles the dataset from Eckhoff \& Haug 2015), it was "find all tokens of verb lemmas marked with the ISO tag chu in reviewed ${ }^{18}$ sentences, as well as their Greek token alignments":

Lemma.find_all_by_language_tag('chu').select $\{|1|$ 1.part_of_speech_tag $==$ 'V-' $\} . m a\}$ $\mathrm{p}(\&$ :tokens).flatten.each do $|\mathrm{v}|$ if v.sentence and !v.sentence.reviewed at.nil? $\mathrm{gk}=\mathrm{v}$. token_alignment end STDOUT.puts [...].join(',')

end

For the diachronic Russian study it was "find all tokens of verb lemmas marked with the ISO code orv in annotated sentences":

Lemma.find_all_by_language_tag('orv').select $\{|\mathrm{vl}|$ vl.part_of_speech_tag $==' \mathrm{~V}$ '\}.map(\&:tokens). flatten.each do $|\mathrm{v}|$

if v.sentence.annotated_at != nil

STDOUT.puts [...].join(',')

end

end

After that, the verb byti was excluded from both datasets, and the OCS dataset was limited to verbs that had an overt Greek aligned verb. All further limitations were done in the R scripts available at doi:10.18710/PUXWXL, together with all datasets.

The basic queries can be approximated in the TOROT webapp simply by querying (under "Search") for all occurrences of OCS and/or Old Russian verb lemmas (or alternatively query for the occurrences of verb lemmas in each of the sources used in the study, since the treebank has grown since the data were drawn). It is also possible to query for individual prefixes under "Semantic tags". What cannot be replicated in this way, however, is the output asked for in the "STDOUT.puts [...].join(',')" statements, which I used to draw large amounts of information on each verb token: treebank-internal identifiers, lemma, morphology and syntax

\footnotetext{
${ }^{18} \mathrm{~A}$ reviewed sentence has been annotated by one annotator and checked and if necessary corrected by another, senior annotator.
} 
information (for example argument structure data) as well as derivational morphology tags. For a full overview of the datasets, see the README-file at doi:10.18710/PUXWXL. While it is possible to download query results in csv or txt format in the TOROT webapp, there is no public way to specify and output the large number of features related to each token found in the datasets - only the token and its left and right context, as well as citation information and the treebank-internal sentence id and token id will be provided.

All reviewed texts in TOROT are released in xml format at http://torottreebank.github.io/ (the Codex Marianus is released by PROIEL at https://proiel.github.io/). The xml files contain lemmatisation, morphological and syntactic information, and information status tags and parallel text token alignment ids where available. They do not contain so-called "semantic tags", the customisable tag layer where the derivational tag information is stored. Thus, it is possible to extract a lot of the information in the datasets from these files using an xml query language, but not all of it.

Given the limited public access to easy data extraction, it is especially important to publish detailed and relatively unlimited datasets of the kind used in this study. 